\title{
A Study on Geotechnical Vulnerability of Collector Road Damage Base on Priority Assessment and PLS-Structural Interaction
}

\author{
Siti Nurjanah Ahmad, Lawalenna Samang, Tri Harianto and Muralia Hustim \\ Department of Civil Engineering, Hasanuddin University, Makassar, Indonesia
}

\begin{abstract}
The annual floods that occur at the study site and and the condition of the swamp pavement the cause of the damage, both minor and severe damage will greatly affect. This study aims to determine the type of damage, improve the condition of pavement and provide information on damaged roads and the geotechnical vulnerability index of road damage. The method of the Pavement Condition Index (PCI) used to evaluate the pavement condition based on the typeand the level of the damage an Analytical Hierarchy Process (AHP) process to assess roads and guide the Indonesian disaster manual to obtain an index for geotechnical road damage. To assess the relationship between factors causing damage to modeling of partial least square-structural equation modeling equations. The results showed $44.47 \%$ damage type with $83.80 \mathrm{M} 2$ width and damage level of PCI 24 at very poor level occurred on Boulevard road, most difficult from road damage condition 0.204, highest score 6.86 on Mokodompit road and lowest on path of Manunggal with index value 3,00 . The interrelationship of the structure-PLS provides the best parameters that directly affect the aspects used with traffic, the Tata modify functions and parameters that do not affect the aspects that create the road network. The results of this study have practical implications as a $m$ eans of identifying the extent of damage to collector roads in municipalities that have swamp areas and unstable groundwater conditions.
\end{abstract}

Key words: Road damage, geotechnical vulnerability index, priority, interaction, PLS provide, Manunggal

\section{INTRODUCTION}

Road damage to many parts of Indonesia is caused by traffic characteristics, excessive vehicle wheel loads, unstable groundwater conditions, poor base soils, geometric factors and pavement road conditions, the quality and quality of inappropriate materials use specifications, economic factors land use financing and unstable road network services (Saing et al., 2017; Saing et al., 2018).

Flood incident that happened in Kendari city as study location became one of the causes of road damage as well as the condition of pavement base ground is a former swamp and the absence of road drainage in some roads causing road damage both minor damage and heavy damage occurred in almost all road segments and greatly disrupting the smooth flow of traffic (Anonymous, 1983a, b, 1995, 2002, 2004a, b).

The implications of geometric aspects of traffic characteristics such as traffic density on roads that are often passed by heavy vehicles can be, easily, damaged compared to roads that are only passed by light vehicles as well as land use and financing aspects, the placement of existing highways in the shopping district will be different from those located in residential areas or educational areas in terms of road users performing activities.

In the last 3 years flood events at study sites causing severe road damage have not been addressed properly and thoroughly. The local government only does patches of local damage due to limited road maintenance fund, so, it is necessary for scientific studies to know the various types of damage what causes it assess the condition of road pavement damage and give which assessment is the priority cause of road damage and also assess how big is the index of vulnerability of geotechnical road damage that occurs, so that, the assessment of the interaction relationship of the causes of the damage can be known to be carried out efforts to overcome the maximum damage by the local government.

Based on the previous description, this study aims to determine the type of damage, assess the condition of road pavement damage and provide a priority assessment

Corresponding Author: Siti Nurjanah Ahmad, Department of Civil Engineering, Hasanuddin University, Makassar, Indonesia 
of the most damaged road segment by assessing the vulnerability index of geotechnical road damage. Using the Pavement Condition Index (PCI) method to assess pavement conditions by type, extent and extent of damage then the Analytical Hierarchy Process (AHP) method was used to assess the priority of road segments this method was chosen because it can convert qualitative analysis into quantitative analysis. It is possible to avoid difficulties and to determine criteria for decision making.

AHP has been widely used to solve decision-making problems with complex structures more decision criteria and factors that are difficult to quantify and assist the assessment process of experts/experts and to determine an interest on the basis of several criteria (Asad et al., 2013; Savitri et al., 2015). Furthermore, Indonesia's disaster risk index manual is used to assess the vulnerability index of road damage geotechnical vulnerability. Specifically to assess the relationship between factors causing road damage, this case study used partial least square based structural equation modeling.

\section{MATERIALS AND METHODS}

Pavement Condition Index (PCI): An appraisal of the pavement condition index is the level of pavement surface condition that refers to the condition and damage to the pavement surface. PCI was developed to provide an index of the integrity of pavement structures and surface coating conditions by logging road damage to information about the cause of the damage and whether the damage was related to vehicle or climate loads. Periodically, surveying road pavement conditions will be useful for predicting future pavement performance or as a more detailed and focused measurement input.

The handling of road damage in Indonesia uses the road maintenance manual issued by the directorate of Bina Marga and the routine maintenance manual for the national road and its repair method, the two manuals are paired with PCI method to analyze all types of damage, cause of road damage, road damage handling process and maintenance process street. This study was conducted on 6 collector road segments in Kendari city, Southeast Sulawesi Province, namely Alala Road (2740 M), Malik Raya Road (1130 M), Boulevard Road (2470 M), Ahmad Dahlan Road (1230 M), Mokodompit Road (2200 M) and Manunggal Road (1600 MAD) but only 2 selected roads represent road damage at the study site. In analyzing road damage by PCI method is done sequentially begins by calculating the density of the damage density can be expressed by the Eq. 1 and 2 :

$$
\begin{aligned}
& \text { Density }=\frac{\mathrm{Ad}}{\mathrm{As}} \times 100 \% \\
& \text { Density }=\frac{\mathrm{Ld}}{\mathrm{As}} \times 100 \%
\end{aligned}
$$

Where:

Ad $=$ Total damage area for each level of damage $\left(\mathrm{m}^{2}\right)$

$\mathrm{Ld}=$ Total length of damage type for each level of damage $\left(\mathrm{m}^{2}\right)$

As $=$ The total area of the segment unit $\left(\mathrm{m}^{2}\right)$

After the CDV is obtained, the PCI for each sample unit is calculated using the Eq. 3:

$$
\mathrm{PCIs}=100-\mathrm{CDV}
$$

The PCI value of pavement as a whole on certain road segments is:

$$
\mathrm{PCI}_{\mathrm{f}}=\frac{\sum \mathrm{PCI}(\mathrm{s})}{\mathrm{N}}
$$

Where :

PCI(s) $=$ PCI for each segment unit

$\mathrm{CDV}=\mathrm{CDV}$ of each sample unit

$\mathrm{PCI}_{\mathrm{f}}=$ Value PCI average of all research areas

$\mathrm{PCI}_{s}=$ Value $\mathrm{PCI}$ for each sample unit

$\mathrm{N} \quad=$ Number of sample units

Furthermore, the classification of pavement quality for the value (PCI) of each segment unit is obtained by calculating the average pavement quality pavement based on certain conditions that are very good, very good, good, medium, broken, very damaged and failed (Anonymous, $2011 \mathrm{a}, \mathrm{b}$ ).

Analysis herarchy process: The perception of an expert in assessing, measuring, formulating and analyzing decisions that involve the subjective factor of the assessment of such experts. AHP is used in the observation of human nature, analysis of thought and measurement that are useful for solving both qualitative and quantitative problems (Abdurrahmad et al., 2016; Savitri et al., 2015). In determining the priority criteria some basic criteria are needed in the weighting of options. The priority setting process of decision making in AHP (Asad et al., 2016; Savitri et al., 2015) includes: 
- Indication of the number of alternatives to be examined

- A review of the dominance of an option against another choice occurs when the performance of an alternative is equally good for all criteria against other alternatives

- Performing the weighting, using matrix pairwise comparison

- Scoring the performance of each alternative by providing a measurable assessment of the criteria variable qualitatively or quantitatively

- Multiplying the weight of each criterion by the score/ranking of alternative performance on the criteria summing the value of each criterion, so as to obtain the total value of an alternative

- Ranking the value, so that, alternative priority is obtained

In this research a perception approach is also, conducted based on expert's opinions to evaluate the criteria of interaction with the sub criteria of road damage at the research site covering. Traffic characteristics criteria (KLL) with sub criteria include: traffic volume, vehicle speed and road capacity. Criteria of road pavement damage condition (KKpj) with sub criteria include: hole damage, grade depression damage, crack damage, wheel ramp damage and road-shoulder damage. Criteria for land use (TGL) with sub criteria include: residential area, trade and service area, education area and industrial area. The geotechnical vulnerability criteria $(\mathrm{KG})$ with its sub-criteria includes: basic soil type, ground water level, pavement layer type and sub-grade road density. Road network criteria (JJ) with sub criteria include: accessibility, mobility and level of road service. The deviation from consistency is expressed by the Consistency Index (CI) of the random matrix with the scoring scale corresponding to Table 1 (Saaty, 2001).

In analyzing the weight of sub-criteria, the data were obtained from a questionnaire constructed on a Likert scale converted to pairwise comparisons as described by
Saaty (2001). The consistency value of the paired comparison of each respondent is then examined. Indicators of consistency are measured through the Consistency Index (CI) formulated as Eq. 5:

$$
\mathrm{CI}=\frac{\lambda_{\max }-\mathrm{n}}{\mathrm{n}-1}
$$

Where:

$\lambda_{\max }=$ The maximum eigen value

$\mathrm{n} \quad=$ The number of elements that are compared

The entire consistency of the assessment is then measured by a Consistency Ratio (CR) by the Eq. 6 :

$$
\mathrm{CR}=\frac{\mathrm{CI}}{\mathrm{RI}}
$$

Where:

$\mathrm{RI}=$ Random Index, the magnitude

$\mathrm{CR}=$ The value of consistency assessment

The consistency ratio of an acceptable respondent's assessment is a maximum of $10 \%$. To get the consensus of all respondents who have a consistency ratio of $<10 \%$ then the following geometic average is used:

$$
\mathrm{G}\left(\mathrm{x}_{1}, \ldots, \mathrm{x}_{\mathrm{n}}\right)=\mathrm{n}_{\mathrm{x}_{1}, \ldots, \mathrm{x}_{\mathrm{n}}}
$$

The priority ranking is obtained by multiplying the value of the parameter (criterion) with the global weight of each sub-criterion and then adding all the results of this multiplication to get a score of each alternative path. The priority score is obtained by the equation:

$$
\text { Priority score }=\sum_{i=1}^{n} P_{i} Q_{i}
$$

\begin{tabular}{|c|c|c|}
\hline Intensity of interest & Definition & Explanation \\
\hline 1 & $\begin{array}{l}\text { Elements that are equally important in comparison with other elements } \\
\text { (equal importance) }\end{array}$ & Both elements contribute equally to that property \\
\hline 3 & $\begin{array}{l}\text { One element is slightly more important than the other elements (moderate } \\
\text { more importance) }\end{array}$ & Experience states a bit in favor of one element \\
\hline 5 & $\begin{array}{l}\text { One element is clearly more important than other elements (essential strong } \\
\text { more important) }\end{array}$ & Experience shows strongly in favor of one element \\
\hline 7 & $\begin{array}{l}\text { One element is clearly more important than the other elements (Demonstrated } \\
\text { Importance) }\end{array}$ & $\begin{array}{l}\text { Experience shows strongly in favor and dominant } \\
\text { practice visible }\end{array}$ \\
\hline 9 & $\begin{array}{l}\text { The one element is absolutely more important than the other (absolutely more } \\
\text { Importance) }\end{array}$ & $\begin{array}{l}\text { Experience shows one element is very clear and } \\
\text { important }\end{array}$ \\
\hline$\underline{2,4,6,8}$ & When in doubt between two adjacent space values (gray area) & This value is given when compromise is required \\
\hline
\end{tabular}

Where:

$\mathrm{P}_{\mathrm{i}} \quad=$ Sub-criterion parameter value

$\mathrm{i}$ and $\mathrm{Q}_{\mathrm{i}}=$ Global weight of sub-criteria $\mathrm{i}$ 
Table 2: Classification vulnerability degree (adopted from IRBI-BNPB) Element values Classification of vulnerability degree $\quad$ Symbol/value $1,000-3,000 \quad$ Low vulnerability degree

$3,100-6,000 \quad$ Moderate vulnerability degree

$\underline{6,100-9,000 \quad \text { High vulnerability degree }}$

Disaster vulnerability index: The determination of the priority scale of the geotechnical vulnerability index value of the road damage adopted the IRBI rules issued by BNPB in 2013 and 2014 on Indonesia's disaster risk vulnerability index which suggests that vulnerability is a condition or occurrence of damage within a region caused by the destruction of physical factors, infrastructure, social, economic and environments which impacts resulting in a decreased ability to deal with hazards. After analyzing the various construct parameters and indicators then proceed with a perception analysis of expert's opinions on the priority of road damage at the research site then the degree of geotechnical vulnerability is analyzed using formulas adapted from the Anonymous (2013), SIDIK (2015) methods, the IKL (Environment susceptibility index) and the regional vulnerability assessment method (Hamzah et al., 2014) into following new formulas:

$$
\mathrm{NIKGK}=\mathrm{IBPKJ} \times \frac{\mathrm{IKKJ}}{\mathrm{IKDW}}
$$

Where:

NIKGK = Value of geotechnical vulnerability index of road damage

IBPKJ = Hazard index trigger of road damage

IKKJ = Vulnerability index of road damage

$\mathrm{IKDW}=$ Value of regional support capacity index

If the vulnerability index has been generated then a classification of vulnerability degree is prepared as presented in Table 2 .

Partial least square-structural equation modeling: Modeling with Structural Equation Modeling (SEM) is an integrated approach between the measurement model, the structural model and path analysis used to solve the multilevel model equations simultaneously with the dependent variable of more than one and also the reciprocal influence that cannot be solved by a linear regression equation (Ghozali, 2004). The PLS method is an alternative approach that shifts from a covarian-based SEM approach to a variance-based. SEM-based covariance generally tests the model of causality/theory while PLS aims to test the predictive relationship or influence between constructs (Asad et al., 2016; Ghozali, 2004). For the analytical approach using SEM-based
PLS includes PLS-based multivariate statistical modeling with Smart PLS 2.0 M3 series software and AHP method, covering:

- Land useconstruct parameters with constructive indicators of residential, commercial, social, office/school/campus and industrial area

- Road network construct parameters with constructive indicators of accessibility, mobility and level of road service

- Road damage condition construct parameters with construct indicators of hole, grade depression, cracks, groove and shoulder drop-off

- Traffic characteristic construct parameters with construct indicator of traffic volume, vehicle speed and road capacity

- Geotechnical vulnerability construct parameters with construct indicators of basic soil type, ground water table, pavement type and sub grade road density

\section{RESULTS AND DISCUSSION}

Assessment rate of road damage: Based on road damage condition using PCI method there were 6 Road segments surveyed and selected roads with the highest level of damage, i.e., Mokodompit and Manunggal road segment and average income of PCI on both roads compared to Table 3. Type of damage that occurred on the road Mokodompit damage pothole with damage area of 39.625 $\mathrm{m}^{2}$ with the percentage of damage $34.419 \%$, alligator cracking cracks with damage area of $14.875 \mathrm{~m}^{2}$ with the percentage of damage $12.921 \%$, patches with an area of damage of $8.688 \mathrm{~m}^{2}$ with damage percentage $7547 \%$, roadside crack with damage area equal to $11.000 \mathrm{~m}^{2}$ with percentage of damage $9.555 \%$, weathering and loose grane with damage area $3.75 \mathrm{~m}^{2}$ with damage percentage $3.257 \%$, city-box crack with damage area $13.75 \mathrm{~m}^{2}$ with damage percentage $11.943 \%$ and damage of rutting with damage area equal to $23.438 \mathrm{~m}^{2}$ with damage percentage 20. $359 \%$. But the most dominant type of damage is hole damage (pothole).

As for the road of Manunggal there is damage to the type of hole (pothole) with damage area of $39.625 \mathrm{~m}^{2}$ with damage percentage $34.419 \%$, crack lengthwise or transverse with damage area equal to $39.625 \mathrm{~m}^{2}$ with damage percentage $34.419 \%$, alligator cracking $14.875 \mathrm{~m}^{2}$ with damage percentage $12.921 \%$, road shoulder damage with damage area equal to $39625 \mathrm{~m}^{2}$ with percentage of damage $34.419 \%$, patch with damage area $8.688 \mathrm{~m}^{2}$ with 
Table 3: Result of calculation of road damage condition by PCI method

\begin{tabular}{|c|c|c|c|c|}
\hline \multirow[b]{2}{*}{ Stations (m) } & \multicolumn{2}{|c|}{ Mokodompit Road } & \multicolumn{2}{|c|}{ Manunggal Road } \\
\hline & Value PCI & Road condition & Value PCI & Road condition \\
\hline $0+000-0+100$ & 38 & Poor & 48 & Fair \\
\hline $0+100-0+200$ & 90 & Perfect & 68 & good \\
\hline $0+200-0+300$ & 25 & Poor & 40 & Fair \\
\hline $0+300-0+400$ & 42 & Fair & 32 & Poor \\
\hline $0+400-0+500$ & 81 & Very good & 56 & Good \\
\hline $0+500-0+600$ & 38 & Poor & 41 & Poor \\
\hline $0+600-0+700$ & 68 & Good & 36 & Poor \\
\hline $0+700-0+800$ & 88 & Perfect & 35 & Poor \\
\hline $0+800-0+900$ & 65 & Good & 78 & Verygood \\
\hline $0+900-1+000$ & 20 & Very poor & 65 & Good \\
\hline $1+000-1+100$ & 78 & Very good & 36 & Poor \\
\hline $1+100-1+200$ & 66 & Good & 31 & Poor \\
\hline $1+200-1+300$ & 35 & Poor & 69 & Good \\
\hline $1+300-1+400$ & 51 & fair & 57 & Good \\
\hline $1+400-1+500$ & 40 & Fair & 70 & Good \\
\hline $1+500-1+600$ & 80 & Very good & 24 & Poor \\
\hline $1+600-1+700$ & 30 & Poor & & \\
\hline $1+700-1+800$ & 34 & Poor & & \\
\hline $1+800-1+900$ & 68 & Good & & \\
\hline $1+900-2+000$ & 34 & Poor & & \\
\hline $2+000-2+100$ & 47 & Fair & & \\
\hline $2+100-2+200$ & 51 & Fair & & \\
\hline $3+200-2+300$ & 40 & Fair & & \\
\hline Amount & 1209 & & 786 & \\
\hline
\end{tabular}

Table .4: The extent and types of damage

\begin{tabular}{lcccc} 
& Mokodompit Road & & Manunggal Road \\
Type of damage & - Area $\left(\mathrm{m}^{2}\right)$ & Kerusakan $(\%)$ & Area $\left(\mathrm{m}^{2}\right)$ & Kerusakan $(\%)$ \\
Hole (pothole) & 39.625 & 34.419 & 13.87 & 19.403 \\
Cracks extend and transverse & - & - & 15.00 & 20.984 \\
Alligator cracking & 14.875 & - & 14.55 & 20.354 \\
Path/descent of road shoulder & - & 7.547 & 5.75 & 8.044 \\
Patch & 8.688 & 9.555 & 7.313 & 10.230 \\
Roadside/side fracture & 11.000 & 3.257 & - & - \\
Weathering and granular discharges & 3.75 & 11.943 & - & - \\
Crack the boxes & 13.75 & 20.359 & 9.75 & 13.640 \\
Rutting & 23.438 & - & 2.00 & 2.798 \\
Basin & - & 100 & 71.483 & 100 \\
Amount & 115.126 & & & \\
\hline
\end{tabular}

damage percentage $7.547 \%$, crack edge/side of road with damage area equal to $11.000 \mathrm{~m}^{2}$ with percentage $9.555 \%$ damage, rutting with damage area equal to $23.438 \mathrm{~m}^{2}$ with damage percentage $20.359 \%$ and damage of basin with damage area equal to $39.625 \mathrm{~m}^{2}$ with damage percentage $34.419 \%$ but the most dominant type of damage is damage crack length/transverse (Table 4).

On both sides of the road that suffered the most severe damage and need serious attention, so that, damage does not increase if not quickly repaired. Damage to both roads causing inconvenience for motorists who use the road, either damaged holes light, medium or heavy hole. This occurs as a result of the development of other types of damage that are not immediately addressed, the effects of weather (especially, rain/flood) and vehicle traffic that exceeds the implied load that accelerates the formation of holes (Fig. 1).
AHP-based priority level: Modeling the priority rank of geotechnical vulnerability to road damage was done with Analytic Hierarchy Process (AHP) approach using pairwise comparison function on criteria as the result is shown in Table 5 (Saaty, 2001). Then the eigen vector line value on the previous matrix and the result are as follows:

Number of line $A=1.000 \times 1.230 \times 1.130 \times 0.961 \times 1.150=5.471$

Determining the amount of wi:

$$
\begin{gathered}
\mathrm{w}_{\mathrm{i}} \text { line } \mathrm{A}=\sqrt[5]{5.471}=1.462 \\
\text { Eigen vector }\left(\mathrm{X}_{\mathrm{i}}\right)=\frac{\mathrm{w}_{\mathrm{i}}}{\sum \mathrm{w}_{\mathrm{i}}}=\frac{1.462}{4.3314} 0.331
\end{gathered}
$$




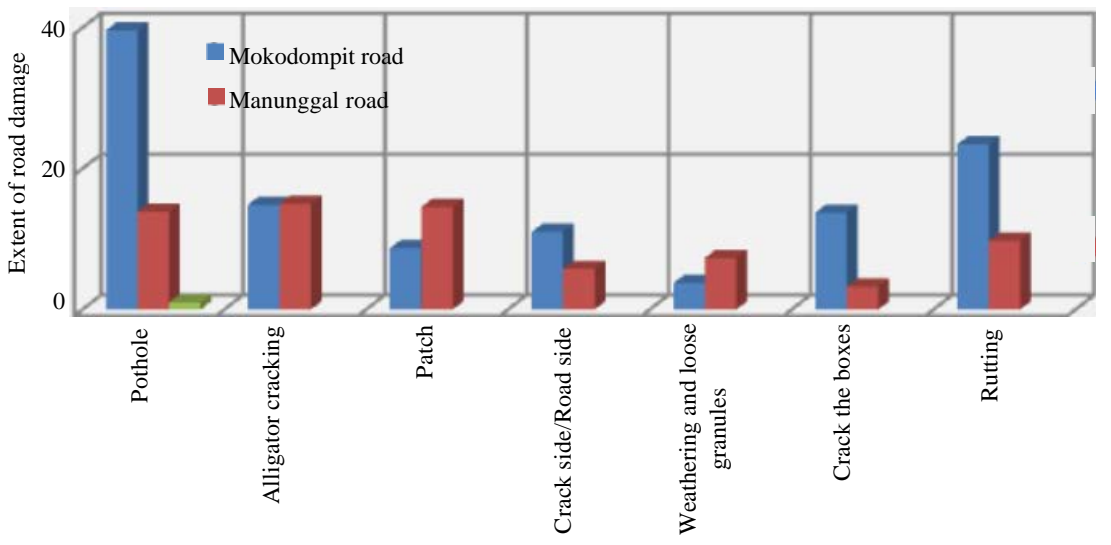

Types of damage

Fig. 1: Area and type of road damage

Table 5: Initial matrix of criteria rating

\begin{tabular}{lcccc}
\hline Criteria & KLL & KKPJ & TGL & KG \\
KLL & 1.000 & 1.230 & 1.130 & 0.961 \\
KKPJ & 0.813 & 1.000 & 1.091 & 1.892 \\
TGL & 0.884 & 0.917 & 1.000 & 1.054 \\
KG & 1.017 & 0.529 & 0.952 & 0.823 \\
JJ & 0.869 & 1.219 & 1.052 & 0.952 \\
$\Sigma$ & 4.583 & 4.895 & 5.225 & 1.000 \\
\hline
\end{tabular}

Table 6: Eigen vector value for scale of determining criteria scale

\begin{tabular}{|c|c|c|c|c|c|c|c|c|}
\hline Criteria & KLL & KKPJ & TGL & $\mathrm{KG}$ & $\mathrm{JJ}$ & Total & $\mathrm{Wi}$ & E-vector \\
\hline KLL & 1.000 & 1.230 & 1.130 & 0.961 & 1.150 & 5.471 & 1.405 & 0.2028 \\
\hline KKPJ & 0.813 & 1.000 & 1.091 & 1.892 & 0.823 & 5.619 & 1.412 & 0.2039 \\
\hline TGL & 0.884 & 0.917 & 1.000 & 1.054 & 0.952 & 4.807 & 1.369 & 0.1976 \\
\hline $\mathrm{KG}$ & 1.017 & 0.529 & 0.952 & 1.000 & 1.232 & 4.730 & 1.364 & 0.1970 \\
\hline JJ & 0.869 & 1.219 & 1.052 & 0.813 & 1.000 & 4.953 & 1.377 & 0.1988 \\
\hline$\underline{\Sigma}$ & 4.583 & 4.895 & 5.225 & 5.720 & 5.157 & 25.580 & 6.928 & 1.0000 \\
\hline
\end{tabular}

The maximum eigen value is obtained from the initial matrix multiplied by evector of each matrix and the result is shown Table 6:

$$
\begin{aligned}
& \begin{array}{|c|ccccc}
\text { Criteria } & \text { KKL } & \text { KKPJ } & \text { TGL } & \text { KG } & \text { JJ } \\
\text { KKL } & 1.00 & 1.230 & 1.130 & 0.961 & 1.150 \\
\text { KKPJ } & 0.813 & 1.000 & 1.091 & 1.892 & 0.823 \\
\text { TGL } & 08.4 & 0.917 & 1.000 & 1.054 & 0.952 \\
\text { KG } & 1.017 & 0.529 & 0.952 & 1.000 & 1.232 \\
\text { JJ } & 0.869 & 1.219 & 1.052 & 0.813 & 1.000
\end{array} \mid \times \\
& \left|\begin{array}{c}
\mathrm{E}-\text { vector } \\
0.2028 \\
0.2039 \\
0.1976 \\
0.1970 \\
0.1988
\end{array}\right|=\left|\begin{array}{c}
\lambda_{\max } \\
1.095 \\
1.121 \\
0.961 \\
0.944 \\
0.992 \\
\text { Total }=5.112
\end{array}\right|
\end{aligned}
$$

Consistency Index $(\mathrm{CI})=\frac{\left(\lambda_{\max }-\mathrm{n}\right)}{(\mathrm{n}-1)}=\frac{(5.112-5)}{(5-1)}=0.028$ Consistency Ratio $=(\mathrm{CR})=\frac{(\mathrm{CI})}{(\mathrm{RI})}=\frac{(0.028)}{(1.12)}=0.025<0.1$ consistency

Consistency Ratio (CR) value is $<0.1$ or equal to $10 \%$ according to the consistency requirement $<0.1$ or $10 \%$. To calculate the element weights, it was obtained from the e-Vector values presented in Table 7. From Table 7 it can be seen that respondent's assessment of some criteria indicates that the criteria of traffic characteristics have an influence of importance level with weight of 0.2028 the road pavement damage condition criterion has an influence of importance level with the weight of 0,2039 land use criteria have an influence of importance level with the weight of 0.1076 the criterion of geotechnical vulnerability has an influence of importance 


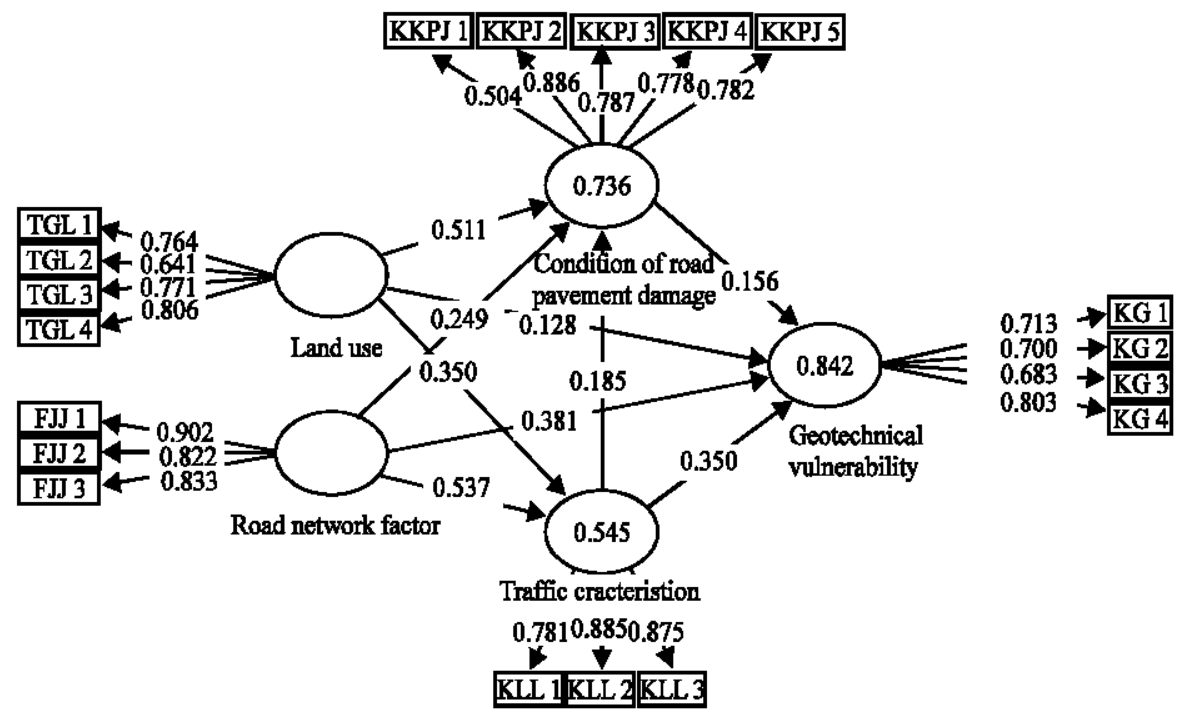

Fig. 2: Path diagram full model

level with the weight of 0.1970 and the criteria of road network factors have an influence of importance level with the weight of 0.1988 . From the various rankings of the sixth street score it can be seen that the score scores have sufficient ability to rank priorities for geotechnical damage in Fig. 2.

Geotechnical vulnerability index of road damage (NIGKJ): The new formula for the geotechnical vulnerability index of road damage (NIGKJ) is then applied to the six roads one of which is as follows. Analysis on Boulevard road segment where:

$$
\mathrm{NIKGKJ}=8.065 \times\left(\frac{3.512}{7.673}\right)=3.6914
$$

In the compilation, the classification of vulnerability degree will consist of low degree of vulnerability, moderate vulnerability and high degree of vulnerability and is calculated according to the classification of vulnerability levels adopted from IRBI-BNPB (Anonymous, 2012, 2013). From the comparison of the scores of the six road segments it is seen that the priority score has sufficient accuracy in determining the priority ranking of geotechnical vulnerability of road damage as described in Table 8.

The classification of vulnerability degree in Table 11 shows that the highest vulnerability index value is 6.7 on HEA Mokodompit road segment which is included in the element value of 6.10-9.00 meaning that the condition of
Table 7: Weight criteria (objective)

\begin{tabular}{lcc}
\hline Sub criteria & Weight & Percentage \\
\hline Traffic characteristics & 0.2028 & 20.28 \\
Condition of road pavement damage & 0.2039 & 20.39 \\
Land use & 0.1976 & 19.76 \\
Geotechnical vulnerability & 0.1970 & 19.70 \\
Road network & 0.1988 & 19.88 \\
Total & 1.0000 & 100.00 \\
\hline
\end{tabular}

Table 8: Classification of geotechnical vulnerability degree of road damage Score/value of Classification of

Road segment vulnerability index vulnerability degree

Mokodompit road

Malik Raya road

Boulevard road

Ir.H. Alala road

Ahmad Dahlan road

Manunggal road

\begin{tabular}{ll}
6.87 & High \\
4.73 & Moderate \\
3.70 & Moderate \\
3.61 & Moderate \\
3.60 & Moderate \\
3.00 & Low \\
\hline
\end{tabular}

damage or vulnerability degree is high. On Malik Raya Road, Boulevard Road, Alala Road and Ahmad Dahlan Roads, the classification of vulnerability degree is moderate while Manunggal road has index vulnerability value of 2.00 which is then included in the classification of low vulnerability level.

Estimation of inner model parameters: Inner model or structural model in PLS analysis describes the strength of relationships between factors (latent variables) (Abdillah and Hartono, 2015; Ghozali, 2004). The interaction relationships between factors in the structural model and the overall indicator shown in the path diagram full model as illustrated in Fig. 1 can be used to measure each construct. The value of the loading factor in Fig. 2 shows all the indicator of the model execution 
Table 9: Parameter of convergent validity test

\begin{tabular}{lll}
\hline Variables & AVE & Remark \\
\hline Land use (TGL) & 0.560 & Valid \\
Road network factors (JJ) & 0.727 & Valid \\
Traffic characteristics (KLL) & 0.719 & Valid \\
Condition of road pavement damage (KRPJ) & 0.554 & Valid \\
\hline
\end{tabular}

Table 10: Varian extraction values of construct average

\begin{tabular}{lcc}
\hline Variables & AVE & AVE root \\
\hline Land use (TGL) & 0.560 & 0.748 \\
Road network factors (JJ) & 0.727 & 0.853 \\
Traffic characteristics (KLL) & 0.719 & 0.848 \\
\hline
\end{tabular}

result is above 0.50. This value represents adequate convergence validity, meaning that one latent variable is able to explain more than half the variants of the indicators in the average (Latan and Ghozali, 2012; Abdillah and Hartono, 2015). It is revealed that road pavement conditions significantly influence the vehicle speed, pavement conditions influence the traffic characteristics. The condition of the pavement is inversely proportional to the speed of the vehicle where the more severe the damage of road pavement the more decreased the vehicle speed.

Convergent validity test : The convergent validity of the measurement model using reflective indicator was assessed by loading factor $>0.7$, AVE $>0.5$ and communality $>0.5$ values. From Table 9 it appears that this model passed a convergence validity test that indicates that the indicator of the same construct has a high correlation (Latan and Ghozali, 2012; Abdillah and Hartono, 2015).

Test of discriminant validity: The measurement of discriminant validity is closely related to the principle that the correlation value of the indicator to its construct must be greater than the correlation value between the indicator and the other construct as shown in Table 9. In Table 10 shows that the correlation value of the indicator to the variable is greater than the value of correlation to other constructs. Fulfillment of discriminant validity test can also be demonstrated by comparing the square root of Average Variance Extracted (vAVE) value of each construct with the construct correlation value with other constructs.

Hypothesis testing (t-test): Is done by using bootstrapping resampling method based on how significant the coefficient of structural model path is the level of significance used in this research is $(\alpha)=5 \%$ or 0.05 with $\mathrm{t}=1.96$. The principles for decision making (hypothesis) If the probability value $\mathrm{p}>0.05$ or the $\mathrm{t}-$ statistic value <t-table value then $H_{0}$ is accepted and $\mathrm{H}_{1}$ is rejected. If the value of probability $\mathrm{p}<0.05$ or tstatistic value $>$ t-table value then $\mathrm{H}_{0}$ is rejected and $\mathrm{H}_{1}$ accepted and obtained partial influence between variables hypothesized in this research which can be justified in Table 11.

Table 11 shows that the hypothesis T3 (1.600), T5 (1.330), T6 (1.560) and T8 (1.209) have p-values >sig. $\alpha$ (0.05), so that, the two alternative Hypothesis $H_{1}$ is rejected and $\mathrm{H}_{0}$ is accepted. It is understood that land use aspect is a moderating variable which can strengthen or weaken the condition of pavement damage to geotechnical vulnerability, for example, hole, grade depression, cracks, wheel trails and road shoulder drop off which may cause damage to the vehicle, accidents for people and vehicles passing and road pavement damage conditions also may influence the speed of the vehicle which implies on the high willingness of people not to pass such broken roads.

Relationship between construct variables: This research analyzed the power of influence between latent variables involving many variables. The level of closeness/strength of the functional relationship was tested by evaluating the direct, indirect and total influence of a construct variable on the other construct variables and the indicator whose results are.

Factors that have a direct influence: Are land use on geotechnical vulnerability road network factors to geotechnical vulnerability condition of road pavement damage variable to geotechnical vulnerability and traffic characteristics to geotechnical vulnerability.

Factors that have an indirect influence include: Land use on geotechnical vulnerability through condition of road damage and traffic characteristics variables, road network factors to geotechnical vulnerability through condition of road damage variable and traffic characteristics and traffic characteristics to geotechnical vulnerability through road damage condition variables. Structural modeling results provide answers to research hypothesis regarding interactions of traffic characteristic, road pavement damage conditions, road network and land use factors and their implications for geotechnical vulnerability to road damage simultaneously. 


\begin{tabular}{|c|c|c|c|c|}
\hline Code & Hypothesis & t-statistic & $\mathrm{p}$-values & Remark \\
\hline$\overline{\mathrm{T} 1}$ & Road network factor with traffic characteristics & 5.217 & 0.000 & $\mathrm{H}_{1}$ rejected \\
\hline $\mathrm{T} 2$ & Road network factor with condition of road pavement damage & 3.620 & 0.000 & $\mathrm{H}_{1}$ rejected \\
\hline $\mathrm{T} 3$ & Road network factor with geotechnical vulnerability & 1.600 & 0.110 & $\mathrm{H}_{1}$ rejected \\
\hline $\mathrm{T} 4$ & Traffic characteristics with condition of road pavement damage & 3.157 & 0.002 & $\mathrm{H}_{1}$ accepted \\
\hline T5 & Traffic characteristics with geotechnical vulnerability & 1.330 & 0.184 & $\mathrm{H}_{1}$ accepted \\
\hline T6 & Condition of road pavement damage with geotechnical vulnerability & 1.560 & 0.119 & $\mathrm{H}_{1}$ rejected \\
\hline $\mathrm{T} 7$ & Land use with traffic characteristics & 3.317 & 0.001 & $\mathrm{H}_{1}$ accepted \\
\hline T8 & Land use with geotechnical vulnerability & 1.209 & 0.227 & $\mathrm{H}_{1}$ accepted \\
\hline T9 & Land use with condition of road pavement damage & 4.375 & 0.000 & $\mathrm{H}_{1}$ accepted \\
\hline
\end{tabular}

\section{CONCLUSION}

In this study in obtained the following conclusions the dominant type of damage is a $44.47 \%$ groove type with a width of $83.80 \mathrm{~m}^{2}$ and the damage value of PCI 24 at a very bad level occurs on the BoulevardRroad. First most important priority is the Mocodompit Road of 4.171 because on this road there is no drainage on the left and right of the Road and the ground is essentially a former swamp. The highest index vulnerability score of 6.87 is on the Mokodompit road segment which is included in the element value of 6.10-9.00 and the Manunggal Road with a vulnerability index value of 3.00 including the low vulnerability classification. The interrelationship of PLS structure interactions resulted in the assessment between the parameters directly affecting the aspects of land use with traffic characteristics, land use with road pavement damage and the effecting parameters did not affect the aspect of pavement damage conditions with the road network.

\section{REFERENCES}

Abdillah, W. and J. Hartono, 2015. [Partial Least Square (PLS) Alternative Structural Equation Modeling (SEM) in Business Research]. Penerbit Andi, Yogyakarta, Indonesia, ISBN:9789792952162, Pages: 272 (In Indonesian)

Anonymous, 1983. Road maintenance manual No.03/MN/B/1983. Directorate General of Highways, Jakarta, Indonesia.

Anonymous, 1983. Routine maintenance manual for national and provincial roads volume II title of standard improvement method No. 002/T/Bt/1995. Directorate General of Highways, Jakarta, Indonesia.

Anonymous, 1995. Technical guidance survey of road engineering planning No. 013/T/Bt/1995. Directorate General of Highways, Jakarta, Indonesia.
Anonymous, 2002. Survey of paved road conditions in urban areas, urban governance and rural governance department of residential and infrastructure. Directorate of Technical Affairs, Jakarta, Indonesia.

Anonymous, 2004. Law of the republic of Indonesia No. 38 of 2004 on Roads. Department of General Workers, Directorate General of Highways, Jakarta, Indonesia.

Anonymous, 2004. Survey guidelines of traffic enumerator Pd.T-19-2004.B. Department of General Workers, Directorate General of Highways, Jakarta, Indonesia.

Anonymous, 2011. Guidance on road condition survey No. 001-04/P/BM/2011. Ministry of Public Works, Jakarta, Indonesia.

Anonymous, 2011. Road survey guideline No. 001 -04/P/BM/2011. Ministry of Public Works, Jakarta, Indonesia.

Anonymous, 2012. General guidelines for disaster risk assessment. National Disaster Management Agency (BNBP), Jakarta, Indonesia.

Anonymous, 2013. Indonesia's Disaster Risk Index (IRBI). National Agency for Disaster Management (BNPB), Jakarta, Indonesia.

Asad, A.M., S. Lawalenna, S.A. Adisasmita and M.I. Ramli, 2013. A comprehensive framework for evaluating the feasibility of upgrading road category based on analytic hierarchy process: Case study in South Sulawesi Province, Indonesia. Proc. East Asia Soc. Transp. Stud., Vol. 9 ,

Ghozali, I., 2004. Structural Equation Modeling: An Alternative Method with Partial Least Square (PLS). 4th Edn., Diponegoro University, Semarang, Indonesia,

Hamzah, S., S.A. Adisasmita, T. Harianto and M.S. Pallu, 2014. Private involvement in sustainable management of Indonesian port: Need and strategy with PPP scheme. Procedia Environ. Sci., 20: 187-196.

Latan, H. and I. Gozali, 2012. Partial Least Square, Concepts, Techniques and Applications Smart PLS 2.0 M3. Diponegoro University, Semarang, Indonesia, 
Saaty, T.L., 2001. The Analyze Hierarchy Process, Planning, Priority, Setting, Resource Allocation. McGraw-Hill Education, New York, USA.,.

Saing, Z., L. Samang, T. Harianto and J. Palanduk, 2018. Bearing capacity characteristic of subgrade layer quicklime treated laterite soil. Proceedings of the 1st International MATEC Web Symposium on Transportation Studies for Developing Countries (ISTSDC 2017) Vol. 181, November 4, 2018, EDP Sciences, Les Ulis, France, pp: 1-7.
Saing, Z., L. Samang, T. Harianto and J. Patanduk, 2017. Study on characteristic of laterite soil with lime stabilization as a road foundation. Intl. J. Appli. Eng. Res., 12: 4687-4693.

Savitri, D.A.W., D.P. Wedagama and I.G.P. Suparsa, 2015. [Analysis of priority determination of handling roads in Denpasar city based on Analytic Hierarchy Process (AHP) method with a combination of Fuzzy Analytic Hierarchy Process (FAHP) and topsis methods (In Indonesian)]. J. Spektran, Vol. 3, 